\title{
Molecular Cloning and Functional Expression of Human Connexin37, an Endothelial Cell Gap Junction Protein
}

Karen E. Reed, “ Eileen M. Westphale, ” David M. Larson," Hong-Zahn Wang, " Richard D. Veenstra," and Eric C. Beyer ${ }^{\star *}$ Departments of ${ }^{*}$ Pediatrics, ${ }^{\ddagger}$ Medicine, and ${ }^{\S}$ Cell Biology, Washington University School of Medicine, St. Louis, Missouri 63110; "Mallory Institute of Pathology, Boston University School of Medicine, Boston, Massachusetts 02118; and "Department of Pharmacology, State University of New York Health Science Center, Syracuse, New York 13210

\begin{abstract}
Gap junctions allow direct intercellular coupling between many cells including those in the blood vessel wall. They are formed by a group of related proteins called connexins, containing conserved transmembrane and extracellular domains, but unique cytoplasmic regions that may confer connexin-specific physiological properties. We used polymerase chain reaction amplification and cDNA library screening to clone DNA encoding a human gap junction protein, connexin37 (Cx37). The derived human $\mathrm{C} 37$ polypeptide contains 333 amino acids, with a predicted molecular mass of 37,238 D. RNA blots demonstrate that $\mathrm{Cx37}$ is expressed in multiple organs and tissues (including heart, uterus, ovary, and blood vessel endothelium) and in primary cultures of vascular endothelial cells. Cx37 mRNA is coexpressed with connexin 43 at similar levels in some endothelial cells, but at much lower levels in others. To demonstrate that $\mathrm{Cx37}$ could form functional channels, we stably transfected communication-deficient Neuro2A cells with the $\mathrm{Cx} 37$ cDNA. The induced intercellular channels were studied by the double whole cell patch clamp technique. These channels were reversibly inhibited by the uncoupling agent, heptanol ( $2 \mathrm{mM}$ ). The expressed $\mathrm{Cx} 37$ channels exhibited multiple conductance levels and showed a pronounced voltage dependence. These electrophysiological characteristics are similar to, but distinct from, those of previously characterized connexins. (J. Clin. Invest. 1993.91:997-1004.) Key words: gap junction • endothelium • intercellular communication • electrophysiology • ion channel
\end{abstract}

\section{Introduction}

Gap junctions are plasma membrane specializations containing intercellular channels that coordinate tissue function by allowing cell-to-cell passage of ions and small molecules. Biochemical and molecular studies have demonstrated that gap junction channels are formed by members of a family of proteins called connexins (1). Topological studies suggest that the extracellular and transmembrane regions of all connexins are highly conserved, whereas the cytoplasmic domains are nearly

Address correspondence to Eric C. Beyer, Division of Pediatric Hematology/Oncology, Box 8116, Washington University School of Medicine, One Childrens Place, St. Louis, MO 63110.

Received for publication 19 June 1992 and in revised form 15 October 1992.

\section{J. Clin. Invest.}

(C) The American Society for Clinical Investigation, Inc.

0021-9738/93/03/0997/08 \$2.00

Volume 91, March 1993, 997-1004 unique to each protein. These connexin-specific sequences may provide unique physiological channel properties. Thus, the channels derived from cloned connexin DNAs expressed in Xenopus oocytes or transfected cells show different biophysical characteristics, including unitary conductance and voltage dependence (2-9).

We have been trying to characterize molecularly the gap junctions between cells of the cardiovascular system, where they play crucial roles in electrical and metabolic function. We have shown that chick heart cells and canine cardiac myocytes express three different gap junction proteins, connexin43 (Cx43), ${ }^{1}$ connexin45 (Cx45), and connexin40 (Cx40, dog) or connexin42 (Cx42, chick) $(10,11)$. These multiple cardiac myocyte connexins likely account for the multiple gap junction channels and voltage-dependent properties observed in these cells $(12,13)$.

The cells of the blood vessel wall also contain gap junctions and express a multiplicity of connexins. Larson et al. (14) reported that endothelial cells, vascular smooth muscle cells, and pericytes all express the same gap junction protein, $\mathrm{Cx} 43$. Lash et al. (15) cloned Cx43 cDNA from bovine aortic smooth muscle cells. However, Moore et al. (16) recently demonstrated that $A 7 r 5$ rat aortic smooth muscle cells express two physiologically distinct gap junctional channels, and Beyer et al. (17) demonstrated that these cells express two connexins, $\mathrm{Cx} 43$ and Cx40.

In the present study, we have identified and molecularly characterized a novel connexin, human connexin37 ( Cx37), which is expressed in another component of the blood vessel wall, the endothelial cell. In fact, in some endothelial cells, the steady state mRNA levels for $\mathrm{Cx} 37$ are similar to those for Cx43, suggesting that this may be a relatively abundant connexin. In addition, we have demonstrated that the protein encoded by this sequence can form functional cell-to-cell channels. Electrophysiological characterization of those channels demonstrates that they have unique voltage-dependence and unitary conductance properties.

\section{Methods}

DNA cloning and sequencing. The initial fragment of mouse $\mathrm{C} \times 37$ was amplified from mouse genomic DNA isolated from J774 cells as described in Beyer and Steinberg (18). We used the PCR (19) with a degenerate/consensus primer corresponding to a conserved sequence in the first connexin extracellular loop (AACACTCTGCAGCCTGGC$\mathrm{TGT}^{\mathrm{A}} /{ }_{\mathrm{G}} \mathrm{A}^{\mathrm{G}} / \mathrm{C} / \mathrm{A} A \mathrm{ACGTCTGCTA} / \mathrm{r}_{\mathrm{T}} \mathrm{GAC}$ ) and an antisense primer corresponding to the second connexin extracellular loop (AGCATGATGATCATGAAGA ${ }^{\mathrm{T}} / \mathrm{c} \mathrm{GGT}^{\mathrm{T}} / \mathrm{c}$ TCNGTGGG). Restriction sites ( $\mathrm{Xhol}$ and BclI, respectively) were incorporated into the primers to facilitate subcloning into Bluescript (Stratagene, Inc., San Diego, CA) or pGEM (Promega, Corp., Madison, WI) vectors. Each PCR cycle consisted of denaturation at $94^{\circ} \mathrm{C}$ for $1 \mathrm{~min}$, annealing at $55^{\circ} \mathrm{C}$ for 2 min, and extension at $72^{\circ} \mathrm{C}$ for $3 \mathrm{~min} .30$ cycles were conducted. 
A cDNA library in lambda gt11 prepared from human umbilical vein cells (20) was a gift from Dr. J. Evan Sadler (Washington University, St. Louis, MO). The cDNA library was screened by hybridization with the DNA fragment of mouse $\mathrm{Cx} 37$ according to Beyer et al. (21) to isolate the full-length human sequence.

DNA sequencing was performed using plasmid templates, Sequenase enzyme (U.S. Biochemical Corp., Cleveland, $\mathrm{OH}$ ), and oligonucleotide primers as previously described (10). Both strands of the fulllength Cx37 cDNA were fully sequenced. DNA sequence acquisition and initial analysis was performed using software (Microgenie; Beckman Instruments, Palo Alto, CA) running on an IBM-compatible microcomputer (22). Protein sequence alignments and comparisons were performed using the CLUSTAL program (23) with the PC Gene software (IntelliGenetics, Mountain View, CA).

DNA and RNA blots. Human genomic DNA was a gift from Dr. Morey Blinder (Washington University, St. Louis, MO) or was purchased from Promega Corp. The genomic DNA was digested with restriction enzymes, electrophoresed in $1 \%$ agarose gels, and transferred to nylon membranes as previously described (24).

For RNA analyses, most tissues were obtained from normal adult rats and mice. Uteri were obtained from 19-d pregnant rats; ovarian tissue was obtained from 21 -d-old female rats stimulated with pregnant mare's serum gonadotropin as in Beyer et al. (21). Essentially pure endothelial tissue was prepared by razor blade scrapings of bovine (calf) aortas as in Larson et al. (14). These initial scrapings are contaminated only by some blood cells ( red blood cells and leukocytes) trapped in adherent fibrin clots. Scrapings prepared in this manner are used to initiate primary cultures of bovine aortic endothelial cells; such cultures contain no morphologically detectable smooth muscle cells. Vital labeling with Dil-Ac-LDL (as in reference 25 ) shows uniform endothelial identification of such cultures (purity must be $>99.9 \%$; Larson, D. M., unpublished data).

Total cellular RNA was prepared from cells or tissues according to Chomczynski and Sacchi (26). RNA was separated on formaldehyde/ agarose gels and transferred to nylon membranes as previously described (21). Hybridization was performed using specific ${ }^{32} \mathrm{P}$-labeled DNA probes prepared using random hexanucleotide primers and the Klenow fragment of DNA polymerase I ( 10 ). In one experiment, $25 \mathrm{ng}$ of the rat Cx43 cDNA and $25 \mathrm{ng}$ of the human Cx37 cDNA were separately labelled and then mixed and hybridized with the blot together to compare relative abundances. In some control experiments, blots were also hybridized with probes for rat $\mathrm{Cx} 40$ or human fibroblast $\gamma$-actin as in previous studies $(17,18)$.

Cell cultures. Mouse Neuro2A (N2A) neuroblastoma cells were obtained from the American Type Culture Collection (Rockville, MD). N2A cells were grown in MEM (GIBCO/BRL, Gaithersburg, MD) supplemented with $10 \%$ heat inactivated $\left(56^{\circ} \mathrm{C}\right.$ for $\left.30 \mathrm{~min}\right)$ fetal calf serum (JRH Biosciences, Lenexa, KS), $1 \times$ non-essential amino acids (GIBCO/BRL), $2 \mathrm{mM}$ L-glutamine, and $100 \mathrm{U} / \mathrm{ml}$ penicillin and $100 \mu \mathrm{g} / \mathrm{ml}$ streptomycin (GIBCO/BRL). A7r5 and other cell lines were grown in DME (GIBCO) supplemented with $10 \%$ fetal calf serum (JRH Biosciences) and $100 \mathrm{U} / \mathrm{ml}$ penicillin and $100 \mu \mathrm{g} / \mathrm{ml}$ streptomycin (GIBCO/BRL). Primary cultures of bovine aortic, bovine retinal microvascular, and human umbilical vein endothelial cells, rat aortic smooth muscle cells, and bovine retinal pericytes were isolated and cultured as described previously (14).

Connexin cDNA transfection. The full-length human Cx37 cDNA was cloned into the EcoRI site of pSFFV-neo (27) N2A cells in 60-mm dishes were transfected with $20 \mu \mathrm{g}$ linearized plasmid using the lipofectin reagent (GIBCO/BRL) according to the manufacturer's directions,

1. Abbreviations used in this paper: $\mathrm{Cx}$, connexin; $g_{\mathrm{j}}$, junctional conductance; $G_{\mathrm{ss}}$, normalized steady state junctional conductance; $I_{1}$, holding current of cell $1 ; I_{2}$, holding current of the nonpulsed cell (cell 2 ); $I_{\mathrm{j}}$, junctional current; $V_{1}$, holding potential of cell $1 ; V_{2}$, holding potential of cell 2 . and stable, neomycin-resistant colonies were selected in $0.5 \mathrm{mg} / \mathrm{ml}$ G418 (GIBCO/BRL). Connexin expression was verified by Northern blotting of total RNA prepared from selected clones.

Electrophysiological studies. Cx37-induced coupling in the transfected N2A cells was studied by double whole-cell recording procedures identical to those described previously (28). Patch electrodes had resistances of 2-4 $\mathrm{M} \Omega$ when filled with a solution with the following composition (mM): $100 \mathrm{~K}$ glutamate, $15 \mathrm{NaCl}, 1 \mathrm{KH}_{2} \mathrm{PO}_{4}, 4.6 \mathrm{MgCl}_{2}, 0.68$ $\mathrm{CaCl}_{2}$, 5 EGTA, $3 \mathrm{Na}_{2} \mathrm{ATP}, 3 \mathrm{Na}_{2}$ Phosphocreatine, 25 Hepes, pH 7.1. The cells were bathed in a solution with the following composition (mM): $142 \mathrm{NaCl}, 1.3 \mathrm{KCl}, 0.8 \mathrm{MgSO}_{4}, 0.9 \mathrm{NaH}_{2} \mathrm{PO}_{4}, 1.8 \mathrm{CaCl}_{2}, 5.5$ dextrose, 10 Hepes, $\mathrm{pH}$ 7.2. All experiments were performed at room temperature $\left(20-22^{\circ} \mathrm{C}\right)$. Transjunctional voltages were elicited by stepping the holding potential of cell $1\left(V_{1}\right)$ from a common value $\left(V_{1}\right.$ $=V_{2}=-40 \mathrm{mV}$ ) to a new value in $10 \mathrm{mV}$ increments between -140 and $+60 \mathrm{mV}$. 6-s duration pulses were applied once every $21 \mathrm{~s}$, except when channel activity was observed and pulse durations were increased to $10 \mathrm{~s}$. Junctional current was taken as the change in holding current of the nonpulsed cell $\left(I_{2}\right)$, since the $I_{1}$ trace contains a nonjunctional membrane current associated with the change in $V_{1}$ in addition to the negative of the $I_{2}$ signal.

\section{Results}

Cloning of human $C x 37$. All connexins studied to date have single copy genes that lack introns in their coding sequences $(29,30)$ and that contain highly conserved sequences corresponding to four transmembrane and two extracellular domains within the proteins (1). We took advantage of these characteristics and used the PCR to attempt to isolate novel connexin sequences. Using oligonucleotide primers corresponding to the two conserved extracellular regions, we amplified several 350-500-bp sequences from mouse genomic DNA that were subcloned and sequenced. One 456-bp sequence clearly corresponded to a portion of a previously unidentified connexin. (The recently reported sequence of Willecke et al. [31] demonstrates that it corresponds to nucleotides 174-630 of mouse Cx37.) High stringency Northern blots performed using this sequence as probe identified an mRNA of $\sim 1.7 \mathrm{~kb}$, which was expressed in many different tissues, but was particularly abundant in endothelial cells (see Fig. 4).

Therefore, to obtain the full-length sequence for this connexin, we used this mouse DNA fragment as probe to screen a cDNA library prepared from human umbilical vein endothelial cells. This cDNA appeared to be relatively abundant in the library, since on rescreening with part of the human sequence we obtained 18 positives from $\sim 200,000$ plaques. Portions of four different clones were sequenced; all overlapped without discrepancies. The sequence of this human connexin cDNA is shown in Fig. 1. It contains 1,601 nucleotides and ends with a poly (A) tail preceded by the poly-adenylation signal AATAAA (32) at bases 1572-1577. There is a long open reading frame that begins with the first ATG (contained within an appropriate consensus for translational initiation) (33) at base 65 . This human cDNA sequence encodes a polypeptide of 333 amino acids with a predicted molecular mass of $37,238 \mathrm{D}$, which we have therefore termed human Cx37.

Comparison of human $\mathrm{Cx} 37$ to the amino acid sequences of other connexins (Fig. 2) demonstrates that this protein is clearly related to other connexins. It is most similar to the $\mathrm{Cx} 37$ recently reported from mouse (31) and rat (34); human Cx37 contains $86 \%$ identical amino acids to each of these proteins (which are $98 \%$ identical to each other). Most of the differ- 


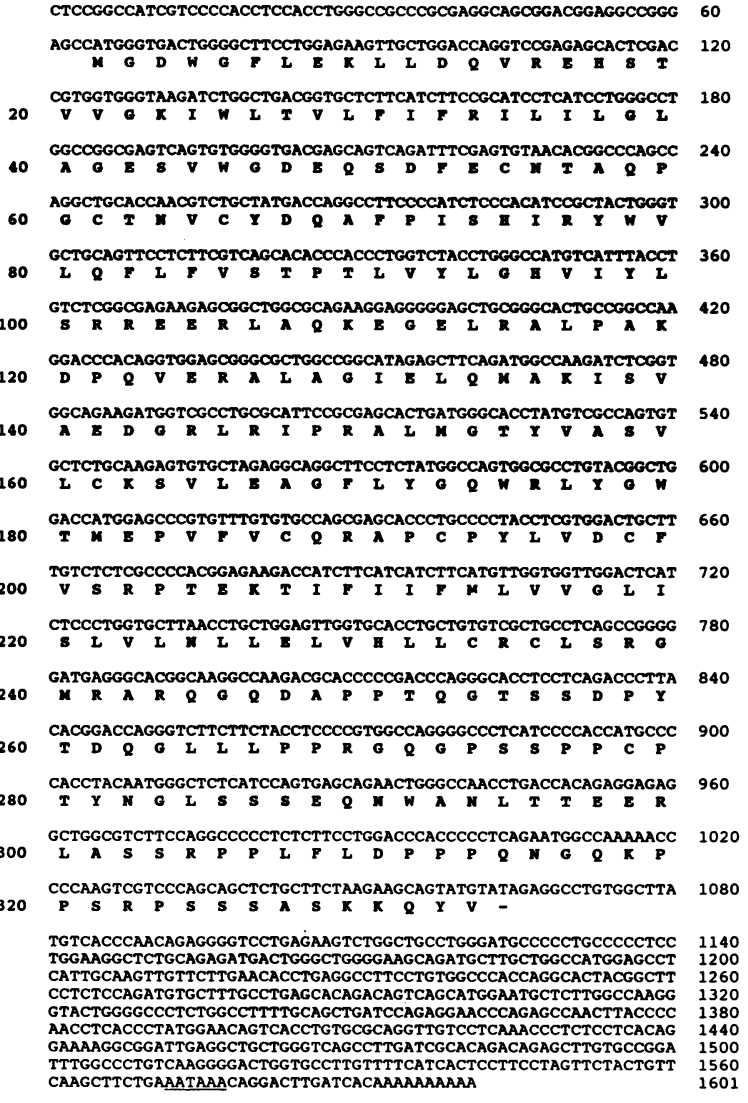

Figure 1. Sequence of human $\mathrm{Cx} 37$. The nucleotide sequence determined from the human umbilical vein cDNA is shown in light type with residues numbered on the right. The derived amino acid sequence is shown in boldface with residues numbered on the left. The putative polyadenylation signal AATAAA is underlined. These sequence data are available from EMBL/Genbank under accession number M96789.

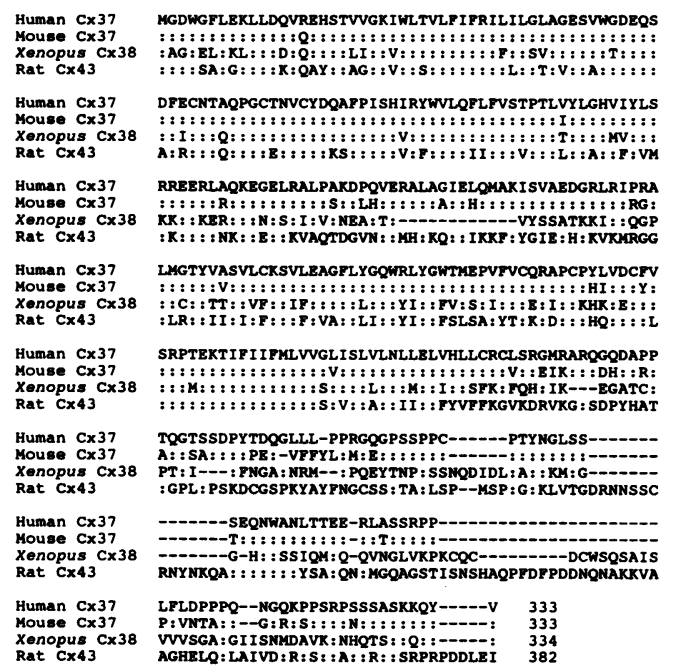

50
50
50
50
100
100
100
100
150
150
138
150
200
200
188
200
250
250
235
250
286
286
273
298
306
3306
335
349

Figure 2. Comparison of human $\mathrm{Cx} 37$ to several closely related connexins. The derived amino acid sequences of human $\mathrm{C} \times 37$ and those of mouse Cx37 (31), Xenopus Cx38 (2), and rat Cx43 (21) are shown as optimally aligned by CLUSTAL (23). Residues that are identical to their counterparts in human $\mathrm{C} \times 37$ are represented by (:); nonidentical residues are listed in single letter code. Dashes represent spaces added to optimize alignment. ences from the rodent sequences fall in regions predicted to be in the cytoplasmic carboxyl-terminal tail. The homology of human $\mathrm{Cx} 37$ to mouse $\mathrm{Cx} 37$ is confirmed by comparison of the nucleotide sequences; $79 \%$ of residues in our sequence are identical to those in the mouse sequence reported by Willecke et al. (31). Many identical residues are found in both the coding region and the 3 '-untranslated region. The 5'-untranslated regions differ; however, the reported mouse sequence was derived from genomic DNA and may contain nontranscribed regions. The sequences of other connexins are somewhat less homologous; they all contain many identical residues in predicted transmembrane and extracellular regions, but few matches in cytoplasmic domains. The next closest connexins are Xenopus Cx38 (50\% identity) and rat Cx43 (48\% identity) (Fig. 2). The predicted cytoplasmic regions of human $\mathrm{Cx} 37$ contain a serine-rich region (residues 301-333) and the sequence SEQNWAN (amino acids 287-293); although the functions of these regions are unknown, they have also been identified in a number of other connexins, which Bennett et al. (35) called class II connexins.

Southern blots. Southern blots of restriction enzyme-digested human genomic DNA were hybridized with human Cx37 probes. As shown in Fig. 3, the Cx37 cDNA probe hybridized only to single bands in multiple enzyme digests, suggesting that human $\mathrm{Cx} 37$ is a single copy gene. The uniqueness of the $\mathrm{Cx} 37$ gene is confirmed by the difference between this blot and published Southern blots probed with other human connexins $(30,36)$. The blots also suggest that, like other connexins, the Cx37 coding sequence contains no introns. PCR amplification using primers derived from the coding or 3'-untranslated regions of $\mathrm{Cx} 37$ gave identical products from genomic DNA or from the cDNA, further supporting the absence of introns in these regions (data not shown).

Expression of $C x 37 m R N A$. To determine the pattern of expression of $\mathrm{Cx} 37$, we performed Northern blot analysis of total RNA isolated from many rodent or bovine organs and tissues. Fig. 4 shows filters probed at high stringency with the probe for mouse $\mathrm{Cx} 37$. Cx37 hybridization was most prominent in heart, uterus, and ovary, but low levels were also detected in many other tissues.

Since Cx37 mRNA was expressed in so many locations, we examined its expression by established cell lines and primary

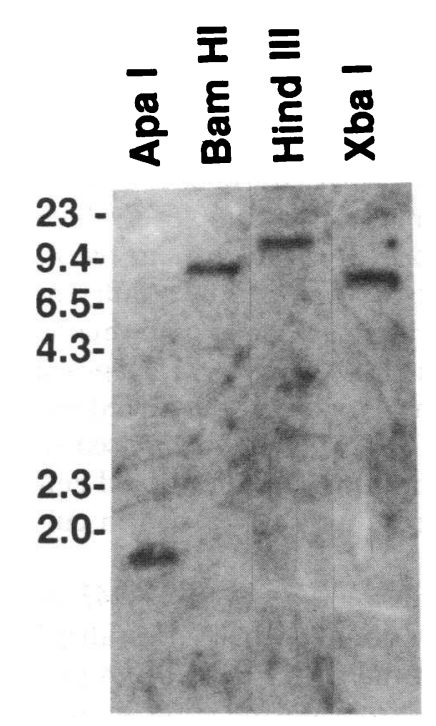

Figure 3. Southern blot analysis of human genomic DNA. DNA was digested with several restriction endonucleases as indicated, separated by agarose electrophoresis, and transferred to nylon membranes. The blot was hybridized with a cDNA probe corresponding to nucleotides $68-603$ of the human $\mathrm{Cx} 37$ sequence. None of the enzymes used has predicted sites within this probe. Lambda phage DNA digested with HindIII was used as molecular mass standards with size in kilobase indicated to the shown, hybridization produced only one band. left of the blot. For all enzymes 


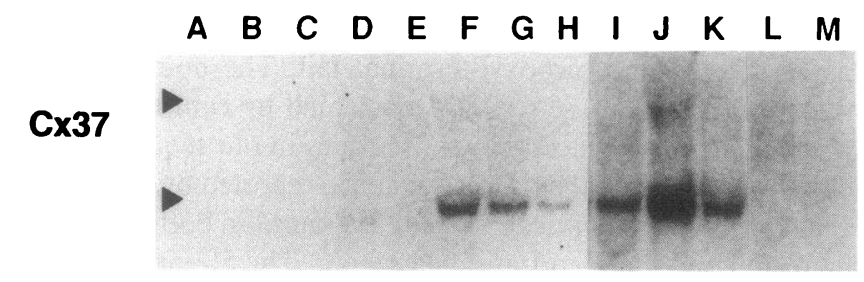

Actin

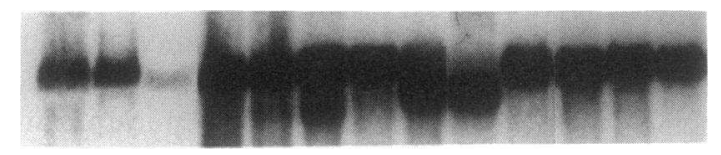

Cx40

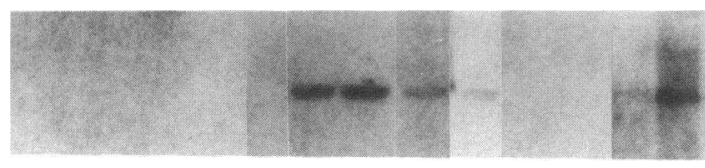

Figure 4. Northern blots demonstrating tissue distribution of expression of Cx37 mRNA. Total cellular RNA was prepared from cells or tissues, separated on formaldehyde/agarose gels ( $10 \mu \mathrm{g}$ per lane) and prepared for Northern blotting as described in Methods. Blots were then incubated with specific ${ }^{32} \mathrm{P}$-labeled DNA probes corresponding to nucleotides $174-630$ of mouse $\mathrm{Cx} 37$. RNAs were prepared from mouse kidney $(A)$, mouse brain $(B)$, mouse liver $(C)$, mouse spleen $(D)$, mouse stomach $(E)$, rat uterus $(F)$, rat ovary $(G)$, rat heart $(H)$, mouse heart $(I)$, human umbilical vein endothelial cells $(J)$, bovine aortic endothelial cells $(K)$, rat aortic smooth muscle cells $(L)$, and $\mathrm{A} 7 \mathrm{r} 5$ rat aortic smooth muscle cells $(M)$. Arrowheads indicate the migration of $18 \mathrm{~S}$ and $28 \mathrm{~S}$ rRNAs. The identical blots were subsequently hybridized with a cDNA probe for human fibroblast $\gamma$-actin (Actin) to examine equivalence of loading and RNA integrity. Identical samples were also hybridized with DNA probes for rat $\mathrm{Cx} 40$ (indicated as $C x 40$ ).

cultures of various cells. Cx37 mRNA was most abundant in RNA derived from primary cultures of endothelial cells from human umbilical vein and bovine aorta (Fig. 4). Other vascular cells (which express $\mathrm{Cx} 40$ or $\mathrm{Cx} 43$ ), including smooth muscle cells and pericytes, did not contain detectable $\mathrm{Cx} 37 \mathrm{mRNA}$. We examined RNA derived from multiple cell lines of different sources, including vascular smooth muscle cells (A7r5, A10), skeletal myoblasts $\left(\mathrm{BC}_{3} \mathrm{H} 1\right)$, fibroblasts (NRK), glioma cells $\left(\mathrm{C}_{6}\right)$, macrophages (J774), hepatoma cells (SK Hep1, $\mathrm{MH}_{1} \mathrm{C}_{1}$ ), and neuroblastoma cells (Neuro2A), but did not detect $\mathrm{C} \times 37$ hybridization (data not shown).

Rehybridization of the blots from Fig. 4 with a control probe for human fibroblast $\gamma$-actin (which hybridizes to the different mammalian actin isoforms under the conditions used ) confirmed the integrity and relative equivalence of loading of the samples, except for the mouse liver sample for which less RNA apparently had been loaded. Because of our recent observation that Cx40 appears to be expressed by a different component of the blood vessel wall (vascular smooth muscle cells), we also hybridized the same RNA samples with a probe for rat $\mathrm{Cx}$ 40. These results, also shown in Fig. 4, confirmed our previous findings that $\mathrm{Cx} 40 \mathrm{mRNA}$, while also expressed in several different organs, was abundant in $\mathrm{A} 7 \mathrm{r} 5$ cells and cultured vascular smooth muscle cells, but not detected in cultured endothelial cells.

To compare the relative expression of $\mathrm{Cx} 37$ and $\mathrm{Cx} 43$ by the vascular endothelial cells, we simultaneously hybridized RNA blots with probes for both connexins (Fig. 5). RNA prepared from endothelium scraped from bovine aorta showed

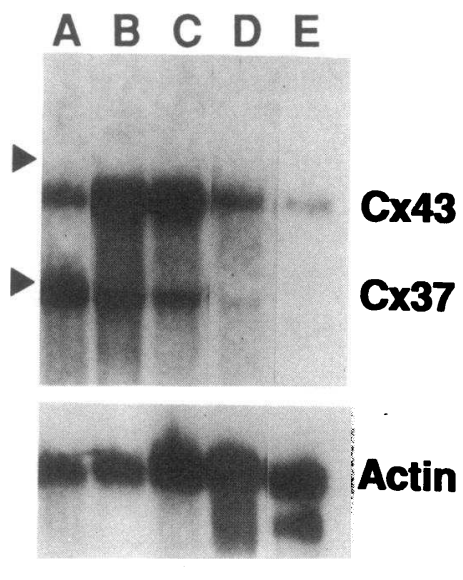

Figure 5. Northern blots comparing expression of $\mathrm{Cx} 37$ and $\mathrm{Cx} 43$ by cultured cells. Total RNA was prepared from fresh scrapings of bovine aortic endothelium $(A)$ or cultured bovine aortic endothelial cells $(B$, $C)$, bovine retinal microvascular endothelial cells $(D)$, or bovine retinal pericytes $(E) .10 \mu \mathrm{g}$ of total RNA was applied in each lane. The blot was hybridized with an equal mixture of identically prepared specific cDNA probes for rat Cx43 (nucleotides 1-1,394) (21), which hybridizes to an mRNA of $\sim 3 \mathrm{~kb}$ and human $\mathrm{Cx} 37$ (nucleotides 68-1,601), which hybridizes to an mRNA of $1.7 \mathrm{~kb}$. The positions of the bands corresponding to $\mathrm{Cx} 43$ and $\mathrm{Cx} 37$ are indicated to the right of the blot. Arrowheads indicate the migration of $18 \mathrm{~S}$ and $28 \mathrm{~S}$ rRNAs. The blot was subsequently rehybridized with a cDNA probe for human fibroblast $\gamma$-actin (Actin) to confirm equivalence of loading and RNA integrity.

hybridization to both the 1.7-kb Cx37 mRNA and the 3-kb Cx43 mRNA. Cx37 and Cx43 both showed strong hybridization to RNA from cultured bovine aortic endothelial cells, although the relative abundance of $\mathrm{Cx} 37$ appeared somewhat less than in the tissue. The relative amounts of Cx37 and Cx43 hybridization appeared nearly identical in two different preparations of RNA from first passage cultures of bovine aortic endothelial cells. In RNA from cultured bovine retinal microvascular endothelial cells, $\mathrm{Cx} 37$ hybridization was much less than $\mathrm{Cx} 43$, and in RNA from the nonendothelial bovine pericytes, only Cx43 was detected. These Northern blots suggest that both $\mathrm{Cx} 37$ and $\mathrm{Cx} 43$ are endothelial connexins, since the mRNAs are so abundant in the freshly isolated tissue and in such homogenous primary cell cultures. We have no data suggesting that $\mathrm{Cx} 37$ in these preparations could derive from other contaminating cell types. Cx37 mRNA was not detectable in RNA prepared from peripheral blood monocytes, monocytederived macrophages, lymphocytes, aortic media, or cultured vascular smooth muscle cells (data not shown). The integrity and relative equivalence of loading of these RNA samples was confirmed by hybridization with the actin probe (Fig. 5). The Cx40 probe did not show significant hybridization with these RNA samples (data not shown).

Functional expression of $C x 37$. To verify that $\mathrm{C} \times 37$ was indeed capable of forming functional cell-to-cell channels and to study the biophysical properties of those channels, we stably transfected the communication-deficient cell line N2A with the human Cx37 cDNA. We have recently used this system to examine the macroscopic and junctional currents induced by three chick embryo cardiac connexins (9). The parent N2A cell line shows no detectable gap junctional channels when screened by double whole cell patch clamp recordings and shows no detectable connexin expression as assayed by Northern blotting with probes for $\mathrm{Cx} 26, \mathrm{Cx} 31, \mathrm{Cx} 32, \mathrm{Cx} 37, \mathrm{Cx} 40$, $\mathrm{Cx} 42, \mathrm{Cx} 43, \mathrm{Cx} 45, \mathrm{Cx} 46$, and $\mathrm{Cx} 56$ (data not shown). Connexin-transfected N2A clones were selected in G418. RNA blot analysis of total RNA prepared from the transfected cells demonstrated that they expressed Cx37 mRNA, whereas no hybrid- 


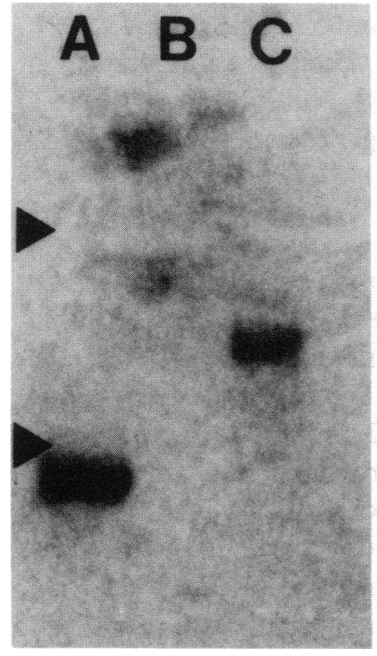

Figure 6. Northern blots demonstrating expression of $\mathrm{Cx} 37$ in transfected cells. Total RNA was prepared from bovine aortic endothelial cells $(A)$, N2A cells transfected with pSFFV-neo vector alone $(B)$, or from N2A cells transfected with pSFFV-neo constructs containing the human Cx37 cDNA sequence $(C)$. Blots containing $10 \mu \mathrm{g}$ per lane were hybridized with the human $\mathrm{Cx} 37$ probe. Arrowheads indicate the migration of $18 \mathrm{~S}$ and $28 \mathrm{~S}$ rRNAs. The $\mathrm{C} \times 37$ hybridizing band in lane $C$ has the expected slower mobility for the vector/cDNA construct than the authentic mRNA alone in lane $A$. ization was detected in cells transfected with vector alone (Fig. 6).

Clones testing positive for connexin expression were examined for functional coupling using the double whole cell recording technique. Electrical communication was evident in $60 \%$ of the pairs examined. Junctional conductance $\left(g_{\mathrm{j}}\right)$ averaged 4.45 $\pm 1.03 \mathrm{nS}$ ( $\pm \mathrm{SEM}, n=7$ ) for Cx37-transfected cell pairs. The external application of pharmacological uncouplers, 1 mM 1-octanol or $2 \mathrm{mM}$ 1-heptanol, reversibly inhibited $g_{\mathrm{j}}$ by $>90 \%$ ( $n=5$ pairs) (see Fig. 7$)$.

In many gap junctions, conductance can be modulated by transjunctional potential $\left(V_{\mathrm{j}}\right)$ gradients (for review see reference 37). To examine the $V_{\mathrm{j}}$ sensitivity of $g_{\mathrm{j}}$ for $\mathrm{Cx} 37, V_{\mathrm{j}}$

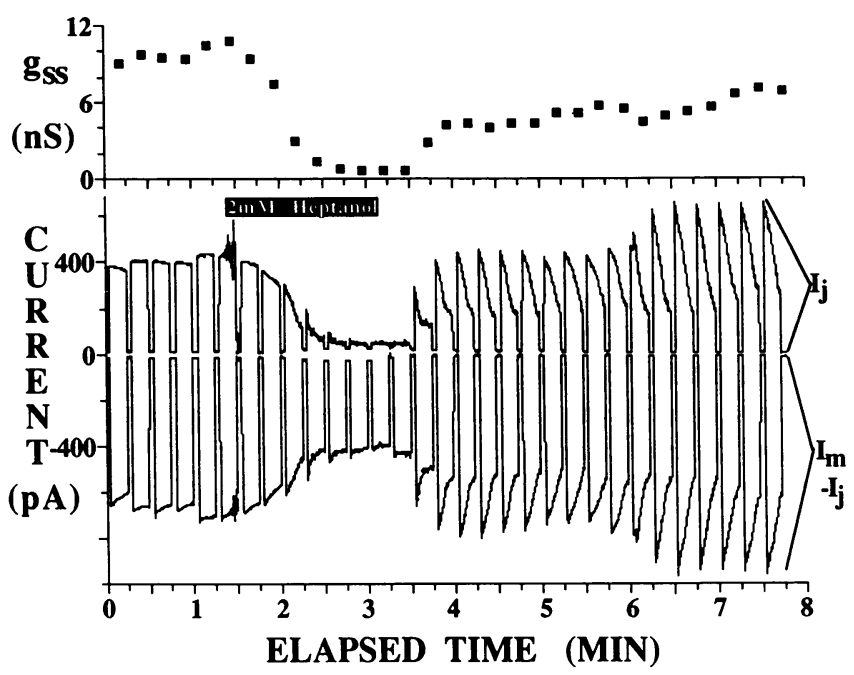

Figure 7. Heptanol blockade of $\mathrm{C} \times 37$-induced junctional conductance. Steady state $g_{\mathrm{j}}\left(G_{\mathrm{ss}}\right)$ was determined from the end of 5-s pulses to $V_{\mathrm{j}}= \pm 40 \mathrm{mV}$ applied at the rate of $4 / \mathrm{min}$ to a $\mathrm{Cx} 37$-transfected cell pair. The top current trace corresponds to the junctional current $\left(I_{\mathrm{j}}\right)$ measured in the nonpulsed cell whereas the currents from the pulsed cell are shown below $\left(I_{m}-I_{\mathrm{j}}\right) .9 \mathrm{~s}$ of each recovery interval $\left(V_{\mathrm{j}}=0 \mathrm{mV}\right)$ between successive pulses were deleted from the current traces for clarity of presentation. $G_{\mathrm{ss}}$ dropped from a control value of 9.87 to $0.82 \mathrm{nS}$ during rapid exposure to $2 \mathrm{mM}$ heptanol added to the bath by bolus injection. Heptanol blockade was slowly reversible by superfusion with normal saline ( $2 \mathrm{ml} / \mathrm{min}, 2 \mathrm{ml}$ bath vol). pulses were applied to paired Cx37-transfected N2A cells. Instantaneous and steady state junctional currents were measured from the first and last $10 \mathrm{~ms}$ of each $V_{\mathrm{j}}$ pulse and junctional current-voltage $\left(I_{\mathrm{j}}-V_{\mathrm{j}}\right)$ relationships were determined for each experiment. In all experiments, the instantaneous $I_{\mathrm{j}}-$ $V_{\mathrm{j}}$ relationships were linear, whereas the steady state $I_{\mathrm{j}}-V_{\mathrm{j}}$ relationships were nonlinear. To illustrate these differences, the steady state $g_{\mathrm{j}}$ was normalized to the instantaneous $g_{\mathrm{j}}$ of each pulse and resulting normalized steady state junctional conductance $\left(G_{\mathrm{ss}}\right)$ was plotted as a function of $V_{\mathrm{j}}$ for each experiment. The average instantaneous and normalized steady state $g_{\mathrm{j}}-V_{\mathrm{j}}$ relationships for $\mathrm{Cx} 37$ are illustrated in Fig. 8. Cx37 conductance underwent a significant reduction ( $>20 \%$ ) in $G_{\text {ss }}$ even at low $V_{\mathrm{j}}$ values $(\leq \pm 20 \mathrm{mV})$. The experimental minimum steady state junctional conductance $\left(G_{\min }\right)$ at $\pm 100 \mathrm{mV}$ was 0.23-0.30.

The $G_{\mathrm{ss}}-V_{\mathrm{j}}$ curve for $\mathrm{Cx} 37$ was mathematically represented by the two-state Boltzmann relationship used to de-
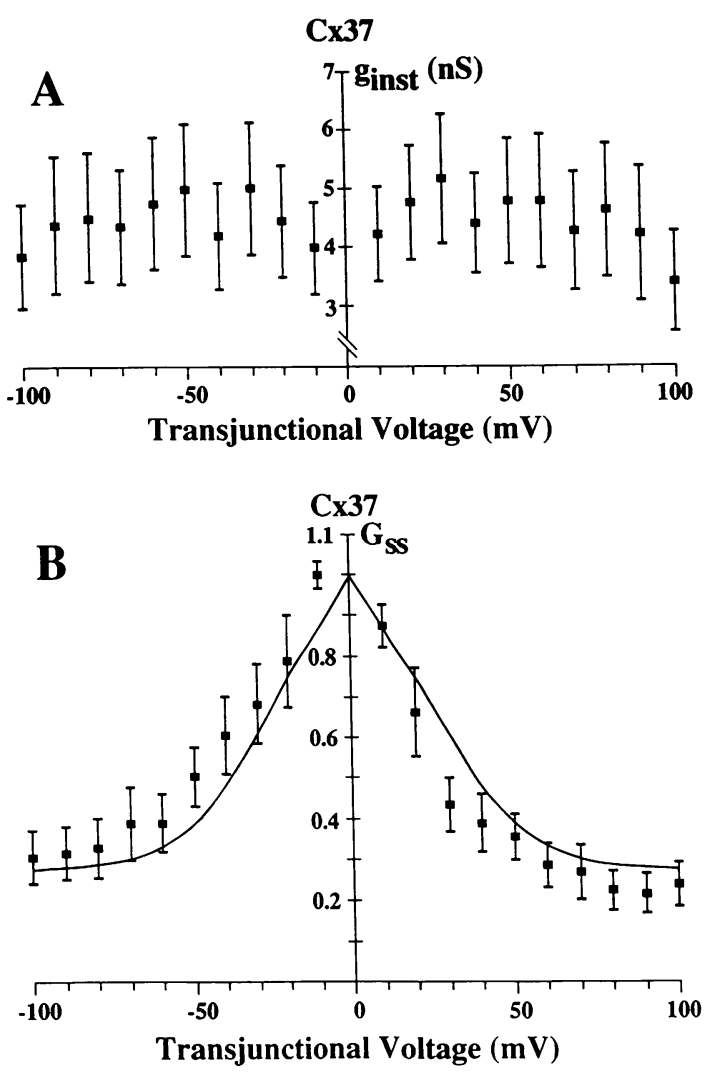

Figure 8. Junctional conductance-voltage relationships for human Cx37. $(A)$ The filled squares and error bars represent the mean instantaneous $g_{\mathrm{j}} \pm$ SEM for all seven $\mathrm{Cx} 37 \mathrm{cDNA}$-transfected N2A cell pairs where a complete $I_{j}-V_{j}$ relationship was obtained. $(B)$ The filled squares and error bars represent the mean $G_{\mathrm{ss}}$ (= steady state $g_{\mathrm{j}} /$ instantaneous $g_{\mathrm{j}}$ ) SEM. The $G_{\mathrm{ss}}-V_{\mathrm{j}}$ relationship for Cx37 was fitted with a theoretical line determined by the Boltzmann relation $G_{\mathrm{ss}}=\left(1-G_{\min }\right) /\left\{1+\exp \left[A\left(V_{\mathrm{j}}-V_{\mathrm{o}}\right)\right]\right\}+G_{\min }$, where $G_{\min }=$ the voltage-insensitive component of $G_{\mathrm{ss}}, V_{\mathrm{o}}=$ the half-inactivation voltage for the voltage-sensitive component of $G_{\mathrm{ss}}$, and $A=$ slope factor expressing the charge sensitivity of the transition between the high and low conductance states. $A$ is determined by the expression $\mathrm{zq} / \mathrm{kT}$, where $z$ is the number of equivalent electrons $q, k$ is Boltzmann's constant, and $T$ is absolute temperature. The values for the relevant parameters are listed in the text. 
scribe other $V_{\mathrm{j}}$-dependent gap junctions (Fig. $8 \mathrm{~b}$ ). According to this analysis, $G_{\mathrm{ss}}$ achieves a $G_{\min }$ of 0.27 at $\pm 100 \mathrm{mV}$ with a half inactivation voltage $\left(V_{o}\right)$ of $\pm 28 \mathrm{mV}$ for the voltage-sensitive component of $G_{\mathrm{ss}}\left(G_{\mathrm{ss}}-G_{\min }\right)$. The slope of the curve ( $A$ $=0.08$ ) is proportional to the number of equivalent electrons that serve as the voltage-sensing mechanism for the voltage-dependent gate, which has a valence of 2.0 for human $\mathrm{Cx} 37$. The two-state Boltzmann equation implies that the time-dependent decay of $I_{\mathrm{j}}$ follows first-order kinetics. Exponential fits of the time-dependent decay of $I_{\mathrm{j}}$ revealed two time constants of 80 $300 \mathrm{~ms}$ and $1-3 \mathrm{~s}$ between $V_{\mathrm{j}}$ values of \pm 50 and $\pm 100 \mathrm{mV}$. Thus, a two-state Boltzmann model is not truly sufficient to describe the kinetics of this time-dependent process, but it does provide a useful indicator for comparing the relative $V_{\mathrm{j}}$ dependence of connexin-specific gap junctions.

Some cell pairs exhibited low levels $(<1 \mathrm{nS})$ of $g_{\mathrm{j}}$ without the addition of pharmacological uncoupling agents, allowing the resolution of single $\mathrm{Cx} 37$ channels. Examples of the junctional current activity obtained under these conditions are illustrated in Fig. 9. In the representative cell pair shown, the expressed $\mathrm{Cx} 37$ channels exhibited a unitary conductance of 200-250 pS at $V_{\mathrm{j}}=30 \mathrm{mV}$; however, larger voltages $(80 \mathrm{mV})$ produced channel conductances of 35-50 and 60-80 pS and a complete absence of $200 \mathrm{pS}$ channels. Gap junction channel activity was observed in six Cx37-transfected cell pairs over a cumulative time of $2 \mathrm{~min}$ with similar results. The combined data from all cell pairs showed that channel conductances averaged $219 \pm 22 \mathrm{pS}$ ( $\pm \mathrm{SD}, n=139$ channel openings ), $165 \pm 6 \mathrm{pS}$

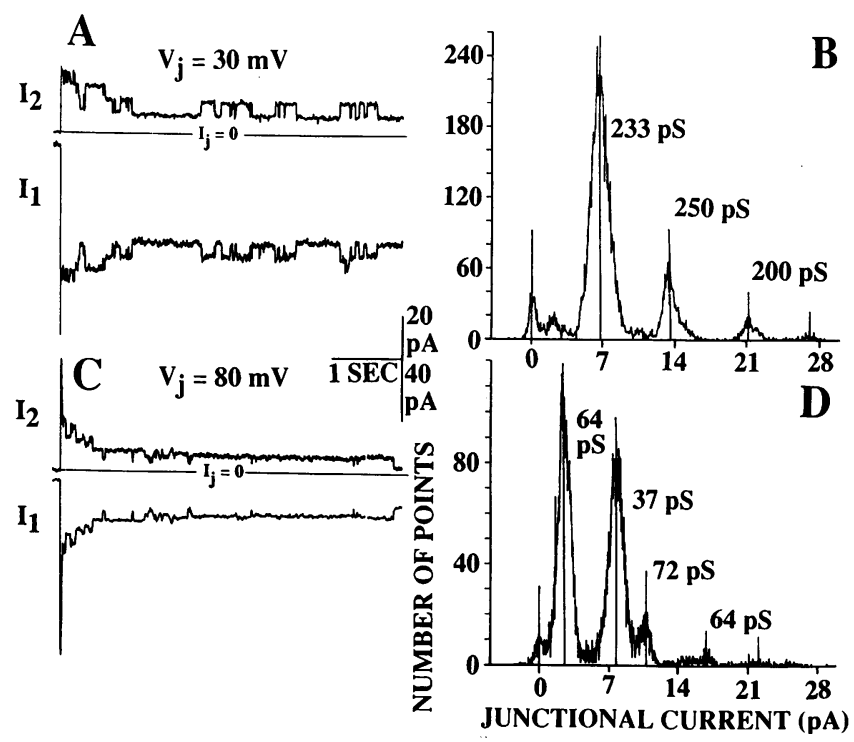

Figure 9. Junctional channel currents obtained from a Cx37 cDNAtransfected N2A cell pair. The left panels $(A$ and $C)$ illustrate the paired whole cell currents $\left(I_{1}\right.$ and $\left.I_{2}\right)$ obtained during a $V_{j}$ pulse to the indicated value ( $30 \mathrm{mV}$ in $A, 80 \mathrm{mV}$ in $C$ ). The $I_{2}$ trace represents the junctional current $\left(I_{j}\right)$ signal. Quantal fluctuations in the upward direction of the $I_{2}$ trace (which are mirrored in the $I_{1}$ trace) represent channel openings. Paired whole-cell currents were recorded from the onset of a 10-s $V_{j}$ pulse applied to a pair of Cx37-transfected cells. All current traces were low-pass filtered at $125 \mathrm{~Hz}$ and digitized at $1 \mathrm{kHz}$. The right panels ( $B$ and $D$ ) show the channel amplitude histograms compiled from the 10 -s junctional current record. The area under each peak is proportional to the time spent in each state. The unitary channel amplitudes shown were calculated from the differences in current between the means of adjacent peaks. $(n=102), 123 \pm 13 \mathrm{pS}(n=172)$, and $53 \pm 1 \mathrm{pS}(n=73)$ at $V_{\mathrm{j}}$ $=30-40 \mathrm{mV}$. At $V_{\mathrm{j}}=80-90 \mathrm{mV}$, channel conductances of $94 \pm 4 \mathrm{pS}(n=39), 69 \pm 5 \mathrm{pS}(n=138)$, and $39 \pm 10 \mathrm{pS}(n=163)$ were observed in the absence of larger channel activity.

\section{Discussion}

We have reported the molecular cloning and functional expression of a novel gap junction protein, human $\mathrm{Cx} 37$. This sequence likely corresponds to the gene that Willecke et al. (38) localized to chromosome 1 pter-q 12 using a mouse $\mathrm{C} \times 37$ probe. Two other human connexins ( $\mathrm{Cx} 32$ and $\mathrm{Cx} 43)$ and a pseudogene $(\mathrm{Cx} 43)$ have been previously reported $(5,36)$.

RNA blots demonstrate that Cx37 mRNA is expressed in many different organs and tissues but is particularly abundant in endothelial cells. In richly vascularized tissues, total RNA samples would be expected to contain a significant proportion of endothelial RNA. Hence, it is likely that endothelial cells in the lung were the source of the mouse $\mathrm{C} \times 37$ reported by Willecke et al. ( 31 ), and endothelium may also explain our finding Cx37 mRNA in heart, uterus, and ovary. However, the marginally detectable Cx37 mRNA in spleen, brain, and cultured microvascular endothelial cells suggests a differential expression in different vascular beds or at different levels of the vasculature. Indeed, electron microscopic studies have demonstrated that the distribution of endothelial gap junctions varies with different vascular beds (for review see reference 39). Pepper et al. (40) recently reported differences in $\mathrm{Cx} 43$ expression and responses to wounding of cultured microvascular and large vessel endothelial cells.

Gap junctions in the blood vessel wall may perform a number of metabolic and electrical functions (39), including the coordination of signal transduction and growth control. Experiments have suggested that vascular gap junctions may coordinate vasomotor responses to humoral agents by mediating cellto-cell spread of a dilating or constricting wave $(41,42)$. The expression of both $\mathrm{Cx} 37$ and $\mathrm{Cx} 43$ by these cells might provide a multiplicity of pathways for such processes. In addition, gap junctions have been implicated in interactions between endothelial cells and other cell types, including smooth muscle cells (43), monocytes (44), and metastatic tumor cells (45). Expression of multiple connexins by endothelial cells might facilitate such interactions.

The expression of both $\mathrm{Cx} 37$ and $\mathrm{Cx} 43$ by endothelial cells is an example of what may be a general cellular strategy: expression of multiple connexins in a single cell. Hepatocytes express Cx26 and Cx32 (46). Cardiac myocytes express Cx40, Cx43, and $\mathrm{Cx} 45$ (11). A7r5 smooth muscle cells express Cx40 and Cx43 (17). Keratinocytes and leptomeningeal cells both express $\mathrm{Cx} 26$ and $\mathrm{Cx} 43(47,48)$. The significance of the expression of multiple connexins and their disparate, but overlapping distributions is unclear. Multiple connexins within a single cell should allow it to form different channels and might coordinate interactions of diverse cell types. It is of interest that our data suggest that two cells of the blood vessel wall both express $\mathrm{Cx} 43$, but one (the endothelial cell) expresses $\mathrm{Cx} 37$, whereas the other (the smooth muscle cell) makes $\mathrm{Cx} 40$.

Our data on the functional expression of human $\mathrm{Cx} 37$ by the stable transfection of N2A cells shows that Cx37 channels are quite voltage dependent. However, our data differ somewhat from those obtained by Willecke et al. (31) when they expressed mouse Cx37 in Xenopus oocytes. We can approxi- 
mate the $G_{\mathrm{ss}}-V_{\mathrm{j}}$ relation for $\mathrm{C} \times 37$ by a simple Boltzmann function whereas they proposed a model with two superimposed gates described by different Boltzmann parameters. The human Cx37 expressed in transfected N2A cells demonstrated a linear instantaneous $G_{\mathrm{j}}-V_{\mathrm{j}}$ relationship; in contrast, Willecke et al. (31) reported a nonlinear instantaneous $G_{\mathrm{j}}-V_{\mathrm{j}}$ relationship for mouse $\mathrm{Cx} 37$, apparently because of the inability of the oocyte voltage clamp to obtain $G_{\mathrm{j}}$ measurements during the first $20 \mathrm{~ms}$ of each $V_{\mathrm{j}}$ step. We did not observe any fast time constants $(<20 \mathrm{~ms}$ ) within the $\pm 100 \mathrm{mV}$ range that could account for these differences between mouse and human Cx37.

It may be that these differences are functional consequences of the differences between the mouse and human sequences. However, the differences may also simply reflect differences of properties observed by voltage clamp in Xenopus oocytes and by whole cell patch clamp in transfected cells; $\mathrm{Cx} 43$, for instance, shows differing voltage-dependence properties in the two systems (3-5). Resolution will require expression of the mouse and human sequences in both systems. However, if the differences are confirmed, mutagenesis experiments to locate residues responsible for voltage dependence should be very straightforward; there are $\geq 10$ amino acid differences (all in predicted cytoplasmic locations) that represent charged amino acid substitutions.

This study provides the first observations of single Cx37 channels. The $\mathrm{C} \times 37$ channels exhibited multiple conductance levels of $\sim 219,165,123$, and $53 \mathrm{pS}$ at low voltages, but appear to be modulated by $V_{\mathrm{j}}$ since unitary conductances of only $\sim 94,69$, and $39 \mathrm{pS}$ were present at $V_{\mathrm{j}}$ values $\geq 80 \mathrm{mV}$. Similar $V_{\mathrm{j}}$-dependent shifts in channel conductances have been observed in embryonic chick heart gap junctions (49).

Finally, these electrophysiological observations demonstrate that $\mathrm{Cx} 37$ channels have different biophysical properties than other molecularly characterized connexins (5-7). The significance of voltage dependence or unitary conductance of gap junction channels is not known, but these have been the beststudied and quantitated properties. These differences raise the possibility that $\mathrm{Cx} 37$ channels might also differ from other connexins in other biologically important properties, such as ion and metabolite permeability or response to intracellular modulators.

\section{Acknowledgments}

We thank Drs. Diane Rup, H. Lee Kanter, and James Laing for helpful and enthusiastic discussions. Mr. Mark Chilton provided valuable technical assistance with tissue culture of the transfected N2A cells, and Radha Narayana provided valuable assistance with the vascular cell cultures.

These studies were supported by National Institutes of Health grants HL45466 (E. C. Beyer and R. D. Veenstra), EY08368 (E. C. Beyer), HL42220 (R. D. Veenstra), and grants from the American Heart Association (CSA 870405 to E. C. Beyer, GIA 900808 to D. M. Larson), the Juvenile Diabetes Foundation (grant \#189934 to D. M. Larson), and the McDonnell Foundation. Eric C. Beyer and Richard D. Veenstra are Established Investigators of the American Heart Association.

\section{References}

1. Beyer, E. C., D. L. Paul, and D. A. Goodenough. 1990. Connexin family of gap junction proteins. J. Membr. Biol. 116:187-194.

2. Ebihara, L., E. C. Beyer, K. I. Swenson, D. L. Paul, and D. A. Goodenough 1989. Cloning and expression of a Xenopus embryonic gap junction protein Science (Wash. DC). 243:1194-1195.
3. Swenson, K. I., J. Jordan, E. C. Beyer, and D. L. Paul. 1989. Formation of gap junctions by expression of connexins in Xenopus oocyte pairs. Cell. 57:145155.

4. Werner, R., E. Levine, C. Rabadan-Diehl, and G. Dahl. 1989. Formation of hybrid cell-cell channels. Proc. Natl. Acad. Sci. USA 86:5380-5384.

5. Fishman, G. I., D. C. Spray, and L. A. Leinwand. 1990. Molecular characterization and functional expression of the human cardiac gap junction channel. J. Cell Biol. 111:589-598.

6. Moreno, A. P., B. Eghbali, and D. C. Spray. 1991. Connexin 32 gap junction channels in stably transfected cells: unitary conductance. Biophys. J. 60:12541266.

7. Moreno, A. P., B. Eghbali, and D. C. Spray. 1991. Connexin 32 gap junction channels in stably transfected cells: equilibrium and kinetic properties. Biophys. J. 60:1267-1277.

8. Barrio, L. C., T. Suchyna, T. Bargiello, L. X. Xu, R. S. Roginski, M. V. L. Bennett, and B. J. Nicholson. 1991. Voltage-dependence at homotypic and heterotypic rat connexin 26 and connexin 32 junctions expressed in Xenopus oocytes. Proc. Natl. Acad. Sci. USA. 88:8410-8414.

9. Veenstra, R. D., H.-Z. Wang, E. M. Westphale, and E. C. Beyer. 1992. Multiple connexins confer distinct regulatory and conductance properties of gap junctions in developing heart. Circ. Res. 71:1277-1283.

10. Beyer, E. C. 1990. Molecular cloning and developmental expression of two chick embryo gap junction proteins. J. Biol. Chem. 265:14439-14443.

11. Kanter, H. L., J. E. Saffitz, and E. C. Beyer. 1992. Cardiac myocytes express multiple gap junction proteins. Circ. Res. 70:438-444.

12. Veenstra, R. D., and R. L. DeHaan. 1986. Measurement of single channel currents from cardiac gap junctions. Science (Wash. DC). 233:972-974.

13. Veenstra, R. D. 1991. Developmental changes in regulation of embryonic chick heart gap junctions. J. Membr. Biol. 119:253-265.

14. Larson, D. M., C. C. Haudenschild, and E. C. Beyer. 1990. Gap junction messenger RNA expression by vascular wall cells. Circ. Res. 66:1074-1080.

15. Lash, J. A., A. S. Critser, and M. L. Pressler. 1990. Cloning of a gap junction protein from vascular smooth muscle and expression in two cell mouse embryos. J. Biol. Chem. 265:13113-13117.

16. Moore, L. K., E. C. Beyer, and J. M. Burt. 1991. Characterization of gap junction channels in A7r5 vascular smooth muscle cells. Am. J. Physiol. 260:C975-C981.

17. Beyer, E. C., K. E. Reed, E. M. Westphale, H. L. Kanter, and D. M. Larson. 1992. Molecular cloning and expression of rat connexin40, a gap junction protein expressed in vascular smooth muscle. J. Membr. Biol. 127:69-76.

18. Beyer, E. C., and T. H. Steinberg. 1991. Evidence that the gap junction protein connexin 43 is the ATP-induced pore of mouse macrophages. J. Biol. Chem. 266:7971-7974.

19. Saiki, R. K. D. H. Gelfand, S. Stoffel, S. J. Scharf, R. Higuchi, G. T. Horn, K. B. Mullis, and H. A. Erlich. 1988. Primer directed enzymatic amplification of DNA with a thermostable DNA polymerase. Science (Wash. DC). 239:487-491.

20. Sadler, J. E., B. B. Shelton-Inloes, J. M. Sorace, J. M. Harlan, K. Titani, and E. W. Davie. 1985. Cloning and characterization of two cDNAs coding for human von Willebrand factor. Proc. Natl. Acad. Sci. USA. 82:6394-6398.

21. Beyer, E. C., D. L. Paul, and D. A. Goodenough. 1987. Connexin43: a protein from rat heart homologous to a gap junction protein from liver. J. Cell Biol. 105:2621-2629.

22. Queen, C., and L. J. Korn. 1984. A comprehensive sequence analysis program for the IBM personal computer. Nucleic Acids Res. 12:581-599.

23. Higgins, D. G., and P. M. Sharp. 1988. CLUSTAL: a package for performing multiple sequence alignment on a microcomputer. Gene (Amst.). 73:237244.

24. Lang, L. M., E. C. Beyer, A. L. Schwartz, and J. D. Gitlin. 1991. Molecular cloning of a rat uterine gap junction protein and analysis of gene expression during gestation. Am. J. Physiol. 260:E787-E793.

25. Voyta, J. C., D. P. Via, C. E. Butterfield, and B. R. Zetter. 1984. Identification and isolation of endothelial cells based on their increased uptake of acetylated low-density lipoprotein. J. Cell Biol. 99:2034-2040.

26. Chomczynski, P., and N. Sacchi. 1987. Single step method of RNA isolation by acid guanidinium-thiocyanate-chloroform extraction. Anal. Biochem. 162:156-159.

27. Fuhlbridge, R. C., S. M. Fine, E. R. Unanue, and D. D. Chaplin. 1988. Expression of membrane interleukin 1 by fibroblasts transfected with murine pro-interleukin $1 \alpha$ cDNA. Proc. Natl. Acad. Sci. USA. 85:5649-5753.

28. Veenstra, R. D. 1990. Voltage-dependent gating of gap junction channels in embryonic chick ventricular cell pairs. Am. J. Physiol. 258:C662-C672.

29. Miller, T., G. Dahl, and R. Werner. 1988. Structure of a gap junction gene: rat connexin32. Biosci. Rep. 8:455-464.

30. Fishman, G. I., R. L. Eddy, T. B. Shows, L. Rosenthal, and L. A. Leinwand. 1991. The human connexin gene family of gap junction proteins: distinct chromosomal locations but similar structures. Genomics. 10:250-256.

31. Willecke, K., R. Heynkes, E. Dahl, R. Stutenkemper, H. Hennemann, S. Jungbluth, T. Suchyna, and B. J. Nicholson. 1991. Mouse connexin37: cloning and functional expression of a gap junction gene highly expressed in lung. $J$. Cell Biol. 114:1049-1057. 
32. Fitzgerald, M., and T. Shenk. 1981. The sequence 5'-AAUAAA-3' forms part of the recognition site for polyadenylation of late SV40 mRNAs. Cell. 24:251-259.

33. Kozak, M. 1987. An analysis of 5'-noncoding sequences from 699 vertebrate messenger RNAs. Nucleic Acids Res. 15:8125-8148.

34. Haefliger, J. A., R. Bruzzone, N. A. Jenkins, D. J. Gilbert, N. G. Copeland, and D. L. Paul. 1992. Four novel members of the connexin family of gap junction proteins: molecular cloning, expression and chromosome mapping. J. Biol Chem. 267:2057-2064.

35. Bennett, M. V. L., L. Barrio, T. Bargiello, D. C. Spray, E. L. Hertzberg, and J. C. Saez. 1991. Gap junctions: new tools, new answers, new questions Neuron. 6:305-320.

36. Kumar, N. M., and N. B. Gilula. 1986. Cloning and characterization of human and rat liver cDNAs coding for a gap junction protein. J. Cell Biol. 103:767-776.

37. Veenstra, R. D. 1991. Physiological modulation of cardiac gap junction channels. J. Cardiovasc. Electrophys. 2:168-189.

38. Willecke, K., S. Jungbluth, E. Dahl, H. Hennemann, R. Heynkes, and K.-H. Grzeschik. 1990. Six genes of the human connexin gene family coding for gap junction proteins are assigned to four different chromosomes. Eur. J. Cell Biol. 53:275-280.

39. Larson, D. M. 1988. Intercellular junctions and junctional transfer in the blood vessel wall. In Endothelial Cells. U. S. Ryan, editor. Cambridge University Press, Cambridge, England. 75-88.

40. Pepper, M. S., R. Montesano, A. El Aoumari, D. Gros, L. Orci, and P. Meda. 1992. Coupling and connexin43 expression in microvascular and large vessel endothelial cells. Am. J. Physiol. 262:C1246-C1257.

41. Segal, S. S., and B. R. Duling. 1986. Flow control among microvessels coordinated by intercellular conduction. Science (Wash. DC). 234:868-870.
42. Segal, S. S., D. N. Daman, and B. R. Duling. 1989. Propagation of vasomotor responses coordinates arteriolar resistances. Am. J. Physiol. 256:H832H837.

43. Davies, P. F., G. A. Truskey, H. B. Warren, S. E. O'Connor, and B. H. Eisenhaure. 1985. Metabolic cooperation between vascular endothelial cells and smooth muscle cells in co-culture: changes in low density lipoprotein metabolism. J. Cell Biol. 101:871-879.

44. Navab, M., F. Liao, G. P. Hough, L. A. Ross, B. J. Van Lenten, T. B. Rajavashisth, A. J. Lusis, H. Laks, D. C. Drinkwater, and A. M. Fogelman. 1991. Interaction of monocytes with cocultures of human aortic wall cells involves interleukins 1 and 6 with marked increases in connexin 43 message. J. Clin. Invest. 87:1763-1772.

45. El-Sabban, M. E., and B. U. Pauli. 1991. Cytoplasmic dye transfer between metastatic tumor cells and vascular endothelium. J. Cell Biol. 115:13751382.

46. Traub, O., J. Look, R. Dermietzel, F. Brummer, D. Hulser, and K. Willecke. 1989. Comparative characterization of the 21-kD and 26-kD gap junction proteins in murine liver and culature hepatocytes. J. Cell Biol. 108:1039-1051.

47. Brissette, J. L., N. M. Kumar, N. B. Gilula, and G. P. Dotto. 1991. The tumor promoter 12-0-tetradecanoylphorbol-13-acetate and the ras oncogene modulate expression and phosphorylation of gap junction proteins. Mol. Cell. Biol. 11:5364-5371.

48. Dermietzel, R., O. Traub, T. K. Hwang, E. Beyer, M. V. L. Bennett, D. C. Spray, and K. Willecke. 1989. Differential expression of three gap junction proteins in developing and mature brain tissues. Proc. Natl. Acad. Sci. USA. 86:10148-10152.

49. Chen, Y.-H. and R. L. DeHaan. 1992. Multiple channel conductance states and voltage regulation of embryonic chick cardiac gap junctions. $J$. Membr. Biol. 127:95-111. 